\title{
Finance and Social Responsibility in the Informal Economy: Institutional Voids, Globalization and Microfinance Institutions
}

\section{Citation}

Liang, Hao, Christopher Marquis, and Sunny Li Sun. "Finance and Social Responsibility in the Informal Economy: Institutional Voids, Globalization and Microfinance Institutions." Harvard Business School Working Paper, No. 15-029, October 2014.

\section{Permanent link}

http://nrs.harvard.edu/urn-3:HUL.InstRepos:13350437

\section{Terms of Use}

This article was downloaded from Harvard University's DASH repository, and is made available under the terms and conditions applicable to Open Access Policy Articles, as set forth at http:// nrs.harvard.edu/urn-3:HUL.InstRepos:dash.current.terms-of-use\#OAP

\section{Share Your Story}

The Harvard community has made this article openly available. Please share how this access benefits you. Submit a story. 
H A R VARD D B U S I N E S S S C H O O L

\section{Finance and Social Responsibility in the Informal Economy: Institutional Voids, Globalization and Microfinance Institutions}

Hao Liang

Christopher Marquis Sunny Li Sun
Working Paper

15-029

October 20, 2014 


\title{
Finance and Social Responsibility in the Informal Economy: Institutional Voids, Globalization and Microfinance Institutions
}

\author{
Hao Liang, Tilburg University ${ }^{1}$ \\ Christopher Marquis, Harvard Business School \\ Sunny Li Sun, University of Missouri-Kansas City
}

October 20, 2014

Keywords: Institutional voids, microfinance institutions, economic globalization, social globalization

\footnotetext{
${ }^{1}$ Authors made equal contribution. Corresponding author: Hao Liang (H.Liang@uvt.nl), P. O. Box 90153, 5000 LE Tilburg. Christopher Marquis (cmarquis@hbs.edu), Sunny Li Sun (suli@umkc.edu).
} 


\title{
Finance and Social Responsibility in the Informal Economy: Institutional Voids, Globalization and Microfinance Institutions
}

\begin{abstract}
We examine the heterogeneous effects of globalization on the interest rate setting by microfinance institutions (MFIs) around the world. We consider MFIs as a mechanism to overcome the institutional void of credit for small entrepreneurs in developing and emerging economies. Using a large global panel of MFIs from 119 countries, we find that social globalization that embraces egalitarian institutions on average reduces MFIs' interest rates. In contrast, economic globalization that embraces neoliberal institutions on average increases MFIs' interest rates. Moreover, the proportions of female borrowers and of poorer borrowers negatively moderate the relationship between social globalization and MFI interest rate, and positively moderate the relationship between economic globalization and MFI interest rate. This paper contributes to understanding how globalization processes can both ameliorate and exacerbate challenges of institutional voids in emerging and developing economies.
\end{abstract}

Keywords: Institutional voids, microfinance institutions, economic globalization, social globalization 


\section{Finance and Social Responsibility in the Informal Economy: Institutional Voids, Globalization and Microfinance Institutions}

Small- and medium-sized enterprises and entrepreneurs around the world frequently face "institutional voids” of credit, that is, in many places there are systematic constraints to obtaining credit stemming from underdeveloped capital and intermediary markets, regulatory systems, contract-enforcing mechanisms and weak or even absent institutional arrangements that support these markets (Khanna \& Palepu, 1997; Mair \& Marti, 2009). In many countries, microfinance institutions (MFIs) have emerged as an important mechanism to overcome such voids by providing small and low-interest loans to low-income individuals for them to establish small businesses (Chakrabarty \& Bass, 2013; Sun \& Im, 2015; Yunus, 2007). Yet, despite the vast literature on the effects of MFIs in facilitating the development of SMEs and small entrepreneurs (e.g. Morduch, 1999; Barr, 2005; Chakrabarty \& Bass, 2013, 2014a, 2014b; Cull, Demirguc-Kunt, \& Morduch, 2007), to date, little is known on how variation in institutional context shapes the extent to which MFIs are effective in bridging these voids (Ault \& Spicer, 2013): What kind of institutions support MFIs to help more poor people escape poverty? How does the institutional context shape MFIs' responses to institutional voids in an increasingly globalized world?

We examine these questions by studying the effect of globalization on MFI operations across developing and emerging economies. The literature on globalization is mixed on the extent to which globalization would ameliorate or exacerbate problems stemming from institutional voids and so affect the operation of MFIs. Positive views on the effects of globalization argue that globalization greatly facilitates trade and information exchange by lowering the restrictions of capital and flow of 
information, which fuels economic growth. In addition, it helps spread egalitarian institutions around the world (Dreher, 2006). The negative view argues that much of the benefits brought by neoliberal-based globalization are enjoyed by developed countries and the formal sectors, while developing countries and the poor population actually suffer from it due to increased competition and income gaps between the rich and the poor (Stiglitz, 2002; Rodrik, 2006). These different effects of globalization could interact with institutional voids to influence organizational strategies and change processes that aim to overcome these voids. For example, globalization that is related to more egalitarian institutions helps reduce the huge information asymmetry between organizations and their stakeholders (e.g., customers and suppliers) that are created by institutional voids, thus significantly increase the bargaining power of the vulnerable and disadvantaged in societies. On the contrary, globalization that is related to more competitive institutions may amplify such asymmetry of information and bargaining power between the advantaged and disadvantaged.

To better identify and understand effects of globalization on how organizations such as MFIs bridge institutional voids, we unpack the multi-dimensional nature of globalization (Brady, Beckfield, \& Seeleib-Kaiser, 2005, Stiglitz, 2002). Social globalization embraces more egalitarian institutions and is associated with the spread of ideas, information, images, and people (Norris, 2000; Dreher, 2006), which help alleviate problems with institutional voids, such as information asymmetry and stereotype. In contrast, economic globalization typically embraces neoliberal economic policies such as facilitating international trade, FDI, portfolio investment, and removal of trade restrictions such as tariffs, capital account restriction and hidden import barriers. Such classification allows us to disentangle its heterogeneous effects on organizational behavior such as that of MFIs in the informal economy. The informal sector served by MFIs is arguably more sensitive to the heterogeneous effects 
of globalization, given its large population and fragile nature (Armendáriz de Aghion \& Morduch, 2005). How globalization influences MFIs' willingness and capability to overcome institutional voids, and how globalization processes and MFIs interact with each other in helping the poor, are the foci of our study.

A key outcome to understand MFI operation and effectiveness is the interest rates they charge their customers. For small entrepreneurs, lower costs of borrowing from MFIs gives informal entrepreneurs easier financing, thus makes it easier for their businesses to operate and survive, which further leads to better development of the informal sector and thus more inclusive growth in the society (Bruton, Khavul, \& Chavez, 2011, Robinson, 2001). That is, interest rate setting largely manifests MFIs' social responsibility in caring about the welfare of poor borrowers across countries informal economies (Sun \& Im, 2015). Therefore, we focus on the heterogeneous effects of globalization on MFIs' micro-credit loan interest rates to small entrepreneurs. If globalization can benefit SMEs and small entrepreneurs, it would help to reduce the barrier of informal entrepreneurs' access to finance (lower microfinance interest rates). However, if globalization has negative effects on SMEs and small entrepreneurs, it would make their access to finance even more difficult (higher microfinance interest rates).

Our paper is distinguished from —and contributes to — the existing literature in at least two central ways. At a basic level, our paper contributes to understanding of the dynamics of institutional voids in emerging economies. The conventional wisdom holds that inclusive growth is fueled by inclusive institutions, which constrain the elite and protects property rights (Acemoglu \& Robinson, 2012). However, as we show in this paper, different types of institutions introduced by globalization can affect organizational behavior in different ways, thus have different implications for social welfare. 
Second, at the organizational level, our paper contributes empirically to the recent resurgence of academic attention on social enterprises and hybrid organizations (Battilana \& Lee, 2014). Social enterprises such as MFIs are emblematic of economy-wide increases in activity at the interface between business and charity, as corporations increasingly engage in social responsibility-related activities, and non-profits increasingly engage in commercial activities to complement their primary, philanthropic sources of funding (Battliana \& Dorado, 2010; Battilana et al., 2012). Our findings about MFIs strategies therefore shed light on how hybrid organizations in the informal economy operate to balance their social mission with financial profitability.

\section{MICROFINANCE IN DEVELOPING AND EMERGING ECONOMIES}

Microfinance is traditionally defined as small loans delivered to low-income entrepreneurs to support business expansion and growth (Ault \& Spicer, 2013; Robinson, 2001; Yunus, 2007). Microfinance has been considered as a tool to address poverty and foster "inclusive growth" by extending financial services to impoverished populations in the informal economy (Van Sandt \& Sud, 2012; Zhao \& Wry, 2014). The rationale is that individuals have the potential to break out of poverty when they have access to loans that enable them to start and grow small businesses - microcredit allows individuals to smooth cash flows, manage risk, cope with economic shocks, and purchase more productive assets, which, in turn, fosters entrepreneurship that has been tied to numerous positive economic and social outcomes (Armedariz de Aghion \& Morduch, 2010; Ault \& Spicer, 2013).

The preponderance of research on MFIs is from economic and finance perspectives. For example, researchers have studied the determinants of the individual microfinance loans, which primarily focus on borrowers' characteristics, such as the poor's credit worthiness (Johnson \& Morduch, 2008), peer 
screening (Michels, 2012), monitoring (Karlan, 2007), and joint liability (Ahlin \& Townsend, 2007).

Others have studied the economic consequences of MFIs, such as poverty reduction (Khandker, 2005) and entrepreneurship (Bruton, Khavul, \& Chavez, 2011). Recently, some scholars have taken the lender's perspective and investigated how microfinance loans are influenced by MFIs organizational characteristics. This line of research usually applies agency theory to the relationship between MFIs' ownership and profitability (Mersland \& Strom, 2008), outreach and financial sustainability (Hartarska \& Nadolnyak, 2007; Im \& Sun, 2014; Quayes, 2011), corporate governance (Mersland \& Strom, 2009; Charkrabarty \& Bass, 2014), and cost efficiency (Caudill, Gropper, \& Hartarska, 2009). While many studies have focused on economic dimensions of micro-credit, less considered is the "hybrid" nature of these organizations. That is, MFIs are social enterprises that on one hand pursue a social mission—-helping the poor—while on the other hand engage in commercial activities that sustain their operations (Im \& Sun, 2014; Mair, 2010). On the social side, MFIs serve the poorest tier of the world's economic pyramid, which comprises more than four billion people, or around 65 percent of the world’s population, who earn less than \$3,000 each per year (Charkrabarty \& Bass, 2013). In this regard, evidence suggests that microfinance positively affects social outcomes such as women’s empowerment, social capital, and economic conditions (Zhao \& Wry, 2014). On the commercial side, most MFIs worldwide face the challenge of making sufficient profit to breakeven, and frequently have to raise fees, which undermines their social mission of helping the poor (Cull, Demirguc-Kunt, \& Morduch, 2007). MFIs’ sustainability as “hybrid organizations” thus depends both on the advancement of their social mission and on their commercial performance (Battliana \& Dorado, 2010; Battilana \& Lee, 2014; Mair, 2010).

Recent recent studies have begun investigating the challenges of scaling while fulfilling social 
mission, finding that, achieving this hybrid ideal is frequently constrained by institutional handicaps. For example, Ault \& Spicer (2013) show how "state fragility" (the failure of the state to act in the public interest) can thwart MFIs' growth, examining several indicators from the World Bank, such as voice and accountability, political stability, government effectiveness, regulatory quality, rule of law, and corruption control. Zhao \& Wry (2014) find that patriarchy norms can suppress the founding of MFIs and their outreach to women, and neoliberal economic policies on one hand attenuate the patriarchal barriers to MFIs' founding, but on the other hand amplify such suppression to women’s lending. These few studies have mainly taken a static view on the institutional determinants of cross-country variation in MFIs' lending, and don't address the dynamics of such institutional effects—especially MFIs' interactions with changing institutions—in an increasingly globalizing world. In our study, we expand the scope of how institutional contexts affect MFIs, and social enterprises in general, by focusing on the effects of globalization that bring heterogeneous institutions into developing and emerging economies.

\section{HYPOTHESIS DEVELOPMENT}

The theory and hypotheses we develop below concern the direct impact of different types of globalization on MFIs' interest rate setting and how these effects are moderated by characteristics of the MFI. As we elaborate, social globalization that is related to more egalitarian institutions helps reduce the information asymmetry between organizations and their stakeholders (e.g., customers and suppliers) that are created by institutional voids, thus significantly increasing the bargaining power of vulnerable and disadvantaged populations and so leading to a positive relationship between social globalization and MFI interest rate. In contrast, globalization that is based on neoliberal institutions tends to increase competition among organizations thus altering industry structure and dynamics that 
are created by institutional voids, which can lead to further expansion of the income gap between the economically advantaged and disadvantaged stakeholders, thus further suppress the disadvantaged.

These processes then lead to a negative relationship between economic globalization and MFI interest rate. Secondly, if these baseline hypotheses are true, it would also imply that less educated and less productive people are less likely to benefit from social globalization, and more likely to be deprived by the economic globalization. Therefore, we also investigate how those "more likely to be deprived" population—female borrowers and the very poor borrowers—-moderate the heterogeneous impact of globalization on MFIs' interest rate setting.

\section{Heterogeneous Effects of Globalization and Institutional Voids}

Globalization that embraces more egalitarian institutions can facilitate information flow, help to reduce information asymmetry and encourage risk sharing (Stiglitz, 1990; 2002). Social change in the form of social globalization creates instrumental, relational, and moral motives for organizations to be more socially responsible through increasing social cohesion and collective responsibility (Aguilera, Rupp, Williams, \& Ganapathi, 2008). These processes are consistent with the egalitarian doctrines that advocate equality for all people and removal of economic inequality across countries and economies (both formal and informal), and information and ideas should be freely shared among all countries (Norris, 2000).

Informal entrepreneurs are typically uneducated, and lack the knowledge, financial literacy and bargaining power to secure low-interest loans and engage in profitable activities as entrepreneurs in the formal sector do (Armendáriz de Aghion \& Morduch, 2005; Webb, Tihanyi, Ireland, \& Sirmon, 2009). Social globalization, by facilitating information sharing and personal contact reduces information asymmetry, can make those uneducated entrepreneurs more knowledgeable and more 
financially literate, and harmonize the informational and knowledge gap between formal and informal entrepreneurs. Consequently, informal entrepreneurs have more bargaining power with MFIs, and MFIs face less information asymmetry from informal entrepreneurs (Cull, Demirguc-Kunt, \& Morduch, 2007; Stiglitz, 1990). In addition, social globalization also helps to fuel social movements by social activists and NGOs, which are strong supporters of egalitarianism, e.g., the development of Fair Trade (Levy, 2008). All these help blur the informational boundaries between the formal sector and the informal sector regarding entrepreneurs' quality of running business and ability of debt repayment, thus release MFIs' concern on default and lower the barrier of informal entrepreneurs' access to micro-credit. Therefore,

H1a. Social globalization reduces MFIs'average loan portfolio interest rates.

In contrast, economic globalization embraces neoliberal policies that facilitates competition across countries and sectors, which gives formal economy actors and formal entrepreneurs more options in the competition for resources. This increases the gap between formal entrepreneurs and informal entrepreneurs in terms of productivity, efficiency, and income (Stiglitz, 2002). In more extreme cases, the force of economic globalization can destroy existing institutions and introduce neoliberal-based institutions which are incompatible with the economic conditions in the informal economy (Bae \& Rowley, 2001, Levy, 2008). From a more micro perspective, neoliberal economic institutions that increase productivity and the income gap can increase the information asymmetry between borrowers (e.g., informal entrepreneurs) and lenders (e.g., MFIs). Consequently, MFIs may have greater incentives to raise the cost of borrowing so as to compensate for such increased information asymmetry. In addition, the interest yields of the small amounts of loans granted to the very poor customers by MFIs are more difficult to cover the costs associated with administration and 
monitoring under stronger competition, given the current business models and fee structures of most MFIs (Johnston \& Morduch, 2008, Mersland \& Strøm, 2010).

The changing economic fundamentals due to economic globalization can further intensify the aforementioned tensions between MFIs and borrowers. On the MFI side, while they may still have a social mission, the increasing competition and income gap would strengthen MFIs' economic orientation, thus they have stronger motivation to pursue economic profit—more similar to other typical commercial organizations_-in relation to social responsibility. On the borrowers' side, the productivity and income gap usually prevent poor borrowers in the informal economy from transforming to more skilled, more educated workers and entrepreneurs (La Porta \& Shleifer, 2014), which further raise the barrier of their access to other sources of finance, thus making them heavily rely on obtaining financing from MFIs (Epstein \& Smith, 2007). Taken together, MFIs’ social responsibility of overcoming institutional voids by providing low-interest micro-credit can be undermined by the heightening competition and income gap brought by economic globalization. Therefore,

H1b. Economic globalization increases MFIs' average loan portfolio interest rates.

\section{The Moderating Effect of Female Borrower Rate}

It is widely recognized that one of the most important missions of MFIs is to empower women by granting more low-interest loans to them (Yunus, 2007; Yunus, Moingeon, \& Lehmann-Ortega, 2010). However, in reality, women are usually deprived from low-interest loans due to their vulnerability to income shocks and higher likelihood of default (Sun \& Im, 2015). Many have argued that globalization helps to mitigate such concerns because globalization can (1) promote gender equality; (2) promote female education; (3) increase job opportunities for women (Cheston \& Kuhn, 2002; 
Milgram, 2001). All these effects empower women by reducing their vulnerability and likelihood of default. In contrast, the opponents of globalization argue that globalization can also adversely affect women, such as increasing forced labor, trafficking, and disproportionate loss of opportunity relative to their male counterparts. Such processes may also reflect the inadequacies of domestic institutions and policies of governments (Johnson \& Kidder, 1999; Milgram, 2001).

Although social globalization reduces information asymmetry and cultural barriers and embraces egalitarianism, its benefits to the poor may still differ across different types of borrowers. In terms of gender difference, female borrowers are often perceived to be less educated, less productive, and less skilled than men in low-income countries. Although social globalization helps to promote education and financial literacy for both genders, women usually improve less than men (Milgram, 2001; Sun \& Im, 2015), and their access to finance is more likely to be suppressed. Extending this logic to the context of borrowing from MFIs, women benefit less from social globalization than men in terms of reduced costs of borrowing (accessing to micro-credit), because women have less personal contact, lower productivity, and so it would have less an effect on their information asymmetry (Bruton et al., 2011; Cull et al., 2007). In other words, men gain more bargaining power from social globalization than women.

Overall, the reduction of barrier to access to finance brought by social globalization is likely to be attenuated by dedication to women borrowers. That is, the more dedicated to female lending the MFI is, the less likely it will take benefits from social globalization and cut interest rates for borrowers. Therefore,

H2a. The female borrower rate of the MFI negatively moderates the relationship in H1a.

We believe that economic globalization is also likely to have different effects on female and male 
borrowers' access to finance in informal economy. On one hand, the positive view of economic globalization suggests that low-income countries have a comparative advantage in labor-intensive productions (mostly low-skilled labors); where women are low skilled, they therefore gain from more neoliberal institutions such as freer trade. On the other hand, the negative view may suggest that high-skilled workers benefit when globalization results in a transfer of technology to low-wage countries; where women are less skilled than men, they are also likely to suffer more than men from the negative effects of globalization (Cheston \& Kuhn, 2002). In the context of economic globalization, which has been hypothesized to suppress entrepreneurs in the informal sector, neoliberal institutions can actually amplify MFIs’ suppression of women’s lending (Zhao \& Wry, 2014). Moreover, increased international trade and foreign investment leads to increased competition, which further increases income inequality between men and women at the bottom of pyramid. That is to say, economic globalization can actually worsen females’ access to low-interest loans by inducing competition and increasing the income-gap between men and women.

Overall, the above arguments suggest that the increase of barrier to access to finance brought by economic globalization can be exaggerated by dedication to women borrowers. The more dedicated to female lending the MFI is, the stronger the effect of economic globalization on MFI's interest rate is. Therefore,

H2b: The female borrower rate of the MFI positively moderates the relationship in H1b.

\section{The Moderating Effect of Poorer Borrowers}

We next look at another important aspect of microfinance lending, namely the amount granted to the very poor borrowers, and how it moderates the effects of social and economic globalization on interest rate setting. Of course most entrepreneurs borrowing from MFIs are poor compared to those in the 
formal sector, but some are much poorer than others, and their micro-credit loan amounts are much smaller. We believe that, similar to female borrowers, poorer borrowers are also likely to benefit less or are deprived more from the heterogeneous effects of globalization. To investigate such effects, we focus on the average amount of loan balance per borrower that the MFI serves. Smaller average amount of loans per borrower indicates that the MFI is more dedicated to serving the poorer population at the bottom of pyramid (Hermes, Lensink, \& Meesters, 2011; Mersland \& Strøm, 2010).

Both as disadvantaged groups, female borrowers and poorer borrowers share a lot of commonalities, and the arguments for the moderating effects of female borrowers can also apply to that of poorer borrowers. In particular, poorer borrowers are generally less educated, less skilled, and less productive, thus benefit less from the positive effects of globalization and suffer more from the negative effects of globalization. More specifically, social globalization reduces information asymmetry of the poor, and gives poor borrowers more financial and entrepreneurial knowledge. Consequently, MFIs will find these poor borrowers are less informationally opaque, and poor borrowers themselves become more financially literate and knowledgeable about loan clauses. All these give poor borrowers stronger bargaining power in relation to MFIs (Bruton et al., 2011; Yunus, 2007). However, such benefits of social globalization are not likely to be enjoyed equally across different borrowers. Due to deficiencies in education, skills, and productivity, poorer borrowers may benefit less from such reduction brought by social globalization. In our context, poorer borrowers are those who borrow smaller amounts of loans, and MFIs which have lower average loan amount per borrower are those that are more dedicated to poorer borrowers. Therefore, while social globalization can help reduce MFIs' interest rates, MFIs that are more dedicated to poorer borrowers (have lower average loan amount per borrower) will have a smaller interest rate cut as compared to other MFIs. 
Therefore,

H3a. The amount of loans to the poor borrowers of the MFI positively moderates the relationship in H1a.

Similarly, for economic globalization, increased international trade and investment leads to an increased income gap between the rich and the poor, and between the poor and the very poor at the bottom of the pyramid. This increases the risk of repayment and financial burden by the poorer borrowers relative to those less-poor entrepreneurs. On the MFIs' side, higher risk of default makes MFIs more reluctant to grant loans with low interest rates to the poorer borrowers (Armendáriz de Aghion \& Morduch, 2005). On the borrowers' side, the lack of education, skills, and productivity usually makes poorer borrowers less competitive in obtaining limited resources, which further raises barriers for their access to finance (Morduch, 1999). All these factors result in poorer people having weaker bargaining power in relation to both MFIs and other less-poor borrowers in competing for limited funding. In other words, due to increased competition for limited resources brought by economic globalization, poorer borrowers are more likely to be deprived by the providers of financing and their competitors. Consequently, while economic globalization functions to raise MFIs' interest rates, MFIs that are more dedicated to poorer borrowers (have lower average loan balance per borrower) will charge even higher interest rates to poorer borrowers, compared to other MFIs with higher average loan amount per borrower. Therefore,

H3b. The amount of loans to the poor borrowers of the MFI negatively moderates the relationship in $H 1 b$.

\section{DATA AND METHODOLOGY}

\section{Data and Sample}


We empirically test the above hypotheses using a large and extensive panel with country- and organizational-level data. MFI’s organizational data were collected from the Microfinance Information Exchange, Inc. (MIX), which focuses on providing comprehensive, objective, and relevant information about microfinance providers and its data is used extensively in microfinance research (e.g., Armendariz de Aghion \& Morduch, 2010; Sun \& Im, 2015). One of the strong features of the MIX data is that the numbers are adjusted by international accounting standards (Cull, Demirguc-Kunt, \& Morduch, 2009). In addition, the data provide not only financial information but also information on the proportion of female borrowers, as well as the legal status of MFIs and their target markets. While the MIX data is fairly comprehensive, it does not cover all MFIs that have ever existed. Therefore, potential concerns may exist regarding self-selection bias with the sample since MFIs voluntarily report information on their activities. However, the organizations that are included represent over 85\% of global microfinance customers, and the data present leading MFIs activities with rigorous reporting standards (Cull et al., 2009; Krauss \& Walter, 2009). Our sample covers 2,306 MFIs from 119 emerging and developing countries around the world over the period 2002-2012.

Data on globalization are from Eidgenössische Technische Hochschule (ETH) Zürich’s KOF Index of Globalization. The Social Globalization Index is constructed by (i) data on personal contact, including telephone traffic, transfers (percent of GDP), international tourism, foreign population (percent of total population), and international letters (per capita); (ii) data on information flows, including internet users (per 1000 people), television (per 1000 people), and trade in newspapers (percent of GDP); (iii) data on cultural proximity, including number of McDonald's Restaurants (per capita), Number of Ikea (per capita), and trade in books (percent of GDP). The Economic Globalization Index is constructed by (i) actual flows, including trade (percent of GDP), foreign direct 
investment stocks (percent of GDP), portfolio investment (percent of GDP), and income payments to foreign nationals (percent of GDP); (ii) restrictions, including hidden import barriers, mean tariff rate, taxes on international trade (percent of current revenue), and capital account restrictions. Both indices are scaled to 0-100. Other country-level variables are from World Bank and World Governance Indicators.

\section{Empirical Strategy}

We apply a multi-level analysis approach in all our regressions. The multilevel quantitative models control for variations at different levels and intragroup correlations (e.g., time and country levels). Multilevel quantitative research has been widely applied in the field of international business (Hitt, Beamish, Jackson, \& Mathieu, 2007; Peterson, Arregle, \& Martin, 2012). Leveraging its advantage in modeling theoretical variables across different level, we build a three-level nested data structure in this study (Holcomb et al., 2010; Klein, Tosi, \& Cannella, 1999; Peterson et al., 2012). Caudill et al. (2009) find that MFIs within a country could share similar regulation, borrowing culture, and economic environment. The same country could induce similar common practices of MFIs (Ahlin \& Townsend, 2007). The issue of intra-class correlation may arise when the variations of the outcome variable at the micro level can be partially explained by explanatory variables at the macro level. For example, in our context, part of the variations in interest rate could be explained by the intra-year or intra-country differences in female borrower rate or average loan balance per borrower (Bliese and Ployhart, 2002). To avoid these cross-level biases, we differentiate three levels in our multilevel analysis: the first is at the time-level, i.e., within-MFI analysis over different time periods; the second is at the country-level, i.e., within-MFI analysis across different countries (especially for those multinational MFIs); the third is at the intra-country level, i.e., within-country analysis across different 
MFIs.

The dependent variable is the one-year forward average gross interests and fees on the focal MFI's loan portfolio (winsorized at 1\%). The focus on MFI's average interest rate of its whole loan portfolio at the aggregated organizational level, rather than at the individual loan level, is because the later says little about MFIs' social responsibility in cutting interest rate for all poor borrowers, but rather about individual borrowers’ capability. The key explanatory variables are country-level social globalization and economic globalization indices (KOF Index of Globalization). Another two key explanatory variables are (1) female borrower rate of the focal MFI, defined as the number of active female borrowers as a percentage of the total number of the MFI's all active borrowers, and (2) average loan balance per borrower as a percentage of GNI per capita (lower value indicates more dedicated to poor borrowers, or deeper outreach to the poor borrowers).

We also control for various country-level, market-level, and organizational-level covariates that are believed to affect MFI's interest rates, which include whether the focal MFI is regulated by the government, the country-level "rule of law" which captures state fragility and institutional quality (Ault \& Spicer, 2013), the size of the "borrower community” that measures the size of the country's aggregate loan balance, the MFI’s years since establishment, the MFI’s debt-to-assets ratio, whether the MFI is registered as a non-profit institution, the MFI's operating efficiency, administrative expense ratio, employee productivity of the focal MFI, the current legal status of the MFI, the scale of the MFI’s loan portfolio size, its target markets, and country-level GDP per capita. The detailed description of each variable is listed in the Appendix.

The descriptive statistics of all our variables are shown in Table 1 . The correlations between independent variables are shown in Table 2. 


\section{RESULTS}

In this section we show results from formal regressions. Column 1 of Table 4 presents the baseline results with only MFI and country characteristics (without globalization variables and their interactions). It is shown in Column 1 that the coefficient on the average loan balance per borrower is negative and statistically significant, i.e., the per-borrower loan balance on average is negatively correlated with average loan portfolio interest rate of the MFI, which implies that the less-poor borrowers can enjoy lower interest rates from the MFI, and potentially indicates that poorer borrowers face higher interest rates, or in other words, are more deprived from access to finance. Similarly, female borrower rate of the MFI is positively correlated with its average loan portfolio interest rate, supporting the argument that women are deprived from easier access to finance under institutional voids, thus MFI that are more dedicated to female borrowing on average charges higher interest rates to borrowers.

In terms of other variables, lower gross nominal interest rates of MFI's loan portfolio is associated with better regulations and better rule of law, which is consistent with the intuition that better domestic institutional environment provide better investor protection and helps lower access to finance (cost of borrowing). This holds not only in the formal economy but also in the informal sector. High employee productivity is associated with lower interest rate. Operating expenses raise interest rate, while leverage ratio (debt to assets ratio) reduces interest rate, and interest rates are lower for MFIs that are registered as "non-profit institutions”, which is consistent with the claimed mission of non-profit organizations. 
Column 2 shows the results when globalization variables enter the regression. Given that the variables Social Globalization and Economic Globalization are both scaled from 0 to 100, they can be (roughly) interpreted as the degree of globalization of the country as a percentage. The coefficient on social globalization is negative and statistically significant at $0.1 \%$ level, which supports $\mathrm{H} 1 \mathrm{a}$, that social globalization can significantly reduce MFI's interest rate, thus the barrier to the poor's access to finance. The economic significance is nontrivial: a one-standard-deviation increase in the degree (percentage) change of social globalization is associated with $0.1 \%$ reduction in MFI's aggregate interest rate, which is remarkable for small-amount loans. In contrast, when Economic Globalization enters into the regression as in Column 3, the coefficient on Economic Globalization is positive and statistically significant at $1 \%$ level, with almost the same (slightly bigger) economic significance, which supports the prediction in H1b, that economic globalization can deprive borrowers from access to finance.

Columns 4 and 5 further include the interaction terms between the organization-level female borrower rate and the country-level social globalization, and between female borrower rate and the country-level economic globalization, as well as their main effects. Column 4 shows that while the main effects of female borrower rate and social globalization still remains the same-negative coefficient on Social Globalization and positive coefficient on Female Borrower Rate-the coefficient of the interaction term “Social Globalization $\times$ Female Borrower Rate” is positive and statistically significant. This implies that female borrower rate negatively moderates the effect of social globalization on MFI’s interest rate. Put differently, the negative association between social globalization and MFI's average loan portfolio interest rate is weaker when the MFI is more dedicated to female lending (the larger proportion of borrowers is women). In addition, Column 5 shows that the 
coefficient of the interaction term "Economic Globalization $\times$ Female Borrower Rate” is also positive and statistically significant (while the main effect of Economic Globalization is positive). This should be interpreted that female borrower rate positively moderates the effect of economic globalization on MFI's interest rate. In other words, the positive association between economic globalization and MFI's average loan portfolio interest rate is stronger when the MFI is more dedicated to female lending. These results are consistent with the notion that less educated and less productive entrepreneurs benefit less from the "bright side" of globalization (social globalization reducing barrier of access to finance) and are deprived more by the "dark side" of globalization (economic globalization raising the barrier of access to finance). Therefore, our H2a and H2b are supported.

Moving to Columns 6 and 7, we examine the moderating effects of MFI's outreach to poorer borrowers. Now the interactions are between Social Globalization and Average Loan Balance per Borrower (Column 6), and between Economic Globalization and Average Loan Balance per Borrower (Column 7). The coefficient on “Social Globalization × Average Loan Balance per Borrower” in Column 6 is negative and statistically significant at the $5 \%$ level, which implies that lower average loan balance per borrower (deeper outreach to poor borrowers) makes the negative relation between social globalization and MFI’s interest rate weaker. Meanwhile, the coefficient on "Economic Globalization $\times$ Average Loan Balance per Borrower” in Column 7 is also negative and statistically significant at the $1 \%$ level, indicating that deeper outreach to the poor borrowers further strengthens the positive relationship between economic globalization and MFI’s interest rate. Again, both moderating effects imply that poorer borrowers benefit less and are deprived more by globalization, which supports our H3a and H3b.

[Insert Table 4 about Here] 
Figure 1 graphically illustrates the moderating effects of female borrower rate and average loan balance per borrower on the effects of social and economic globalization on MFI's average loan interest rate. The graphs confirm our empirical findings. In general, the slopes for social globalization are negative (Figures 1A and 1C), indicating that social globalization is negatively related to MFIs' average interest rate, while the slopes for economic globalization are positive (Figures 1B and 1D), indicating that the association between economic globalization and MFIs' interest rate is negative.

Female borrower rates and poor borrowers (measured by average loan balance per borrower) also have strong moderating effects, as the slopes for higher female borrower rates and lower female borrower rates differ substantially in Figures $1 \mathrm{~A}$ and $1 \mathrm{~B}$, and that for higher and lower average loan balance per borrower are also significantly different in Figures 1C and 1D. Overall, the heterogeneous effects of globalization and the moderating effects of disadvantageous borrower population are conspicuous on graphs.

\section{[Insert Figure 1 about Here]}

To check the robustness of the previous results, we have conducted several additional tests by including additional controls and using different estimation methods. One concern may be that the interest rate setting also depends on the width and depth of the borrower base, which may not be captured by our control variables. Therefore, we further include in our regressions two additional controls: MFI's outreach (winsorized) and the country's total population. In addition, given that our key variables of interest—social and economic globalizations—are at the country-level, one may worry about other alternative country-level channels that are related to globalization but also simultaneously affecting interest rate setting, such as culture and legal systems. We therefore also control for country fixed effects, and report the new results in Table 5. To preserve space we only 
report the coefficients on the key explanatory variables, but the same control variables are included. As shown in Table 5, the previous results still survive: higher degree of social globalization is associated with lower loan portfolio interest rate, while female borrower rate and lower average loan balance per borrower negatively moderate such relationship. In contrast, higher degree of economic globalization is associated with higher interest rate, while female borrower rate and lower average loan balance per borrower positively moderate such relationship.

[Insert Table 5 about Here]

To explore the source of the heterogeneous effects of globalization, we go step further and investigate the effect of different components of social globalization and of economic globalization. This allows us to better understand which aspects of globalization contribute more to MFI's interest rate setting. We therefore replace Social Globalization with its three main components (sub-indices) as mentioned in the Data and Methodology section: Personal Contact, Information Flows, and Cultural Proximity, and replace Economic Globalization with its two main components (sub-indices): Actual Flows and Restrictions (by construction, higher value of "Restrictions" indicates fewer trade restrictions; see variable description in Appendix). Several interesting observations emerge from Table 6. First, the statistical significance of each individual component of Social Globalization and of Economic Globalization is smaller (sometimes even insignificant) than the aggregate social and economic globalization scores, indicating that the effects of globalization are complementary to each other, rather than substitutive. Second, the moderating effect of female borrower rate is stronger for the individual components of Economic Globalization (Actual Flows and Restrictions), but not for that of Social Globalization, as the coefficients on the interaction terms between Social Globalization and Personal Contact, Information Flows, and Cultural Proximity are not statistically significant. Third, the 
moderating effect of poorer borrowers (smaller average loan balance) is significant for Information Flows, Cultural Proximity, and Actual Flows, but not for Personal Contact and Restrictions, indicating there are differential interaction effects of different aspects of social and economic globalization with poor borrowers' existing financial conditions on their future costs of borrowing (access to finance).

[Insert Table 6 about Here]

\section{DISCUSSION}

Researchers and policymakers are increasingly paying attention to "inclusive growth": advancing equitable opportunities for economic participants during the process of economic growth with benefits incurred by every section of society (Ianchovichina \& Lundstrom, 2009). Inclusive growth not only advocates the growth of the formal economy which consists of large firms financed by capital markets, but also focuses on the development of informal economy which consists of informal firms, small entrepreneurs, and micro-credit granted to them so as to provide livelihood of billions of very poor at bottom of the pyramid, especially in developing countries (Prahalad, 2005). However, the informal economy, which hosts the world's billions of low-income population, suffers most from institutional voids characterized by the lack of formal rules governing economic activities and market institutions facilitating transactions. Yet, how different players in this segment of the economy interact with institutions and institutional voids remain largely unexplored. In this paper, we examined a particular mechanism that emerges to overcome institutional voids in the informal economy: the microfinance institutions which provide access to finance to help the poor and small entrepreneurs. We examine how MFIs' functioning (“social responsibility”) is influenced by globalization that embraces different types of institutions. We focus on the interest rate setting of MFIs as it is their main function and 
social responsibility in helping the poor, as lower interest rates provide the poor and informal entrepreneurs with easier access to credit, and we focus on the economic and social aspects of globalization as they embrace confounding institutions.

Using an extensive sample of organizational level data on MFIs from 119 developing and emerging countries, we find that globalization has heterogeneous effects on MFI's interest rate setting (i.e. their social responsibility). In particular, social globalization that embraces egalitarian institutions—-facilitating information flows, personal contact and cultural proximity—helps reduce MFI's average portfolio loan interest rate, while economic globalization that embraces neoliberal institutions—-facilitating competition in international trade, investment, and other capital flows as well as reduction of capital flow barriers_-increases MFI’s average loan portfolio interest rate. In addition, MFI's outreach to female borrowers and poorer borrowers—-two most prominent missions of MFI's social responsibility—negatively moderates the relation between social globalization and interest rate, and positively moderates the relation between economic globalization and interest rate. These indicate that the less educated and less productive population in informal economy benefit less from and are deprived more by new neoliberal-oriented institutions.

\section{Contributions to Understanding Multifaceted Effects of Globalization.}

In recent years, economists have realized the multifaceted effects of globalization around the world, though mostly at the country-level (Stiglitz, 2003; Rodrik, 2006). Relatively little is known about such heterogeneous effects of globalization at the organizational level, especially in the informal economy. Institutional voids of credit in developing and emerging economies provide us an opportunity to investigate such micro-level impact. As shown by our results, different facets of globalization do influence MFIs' lending decision and poor borrowers' access to finance differently. 
Our findings therefore shed light on both the bright side and the dark side of globalization from the perspectives of how social organizations (MFIs) can serve the global poor. These organization-level findings, together with Mair, Marti, \& Ventresca (2012) and Johnson \& Kidder (1999), complement the country-level evidences to provide a more complete picture of globalization's effects.

The findings on the multifaceted effects of globalization also extend the scope of the study of business and poverty in general (e.g., Ault \& Spicer, 2013), and have strong policy implication on the role of the informal economy in society. Our findings are consistent with the dual perspective of the informal economy (La Porta \& Shleifer, 2014), and contradict ideas that suggest the benefits of neoliberal-based economic globalization that advances the formal sector will "trickle-down" to the informal sector to make the poor relieved from financial constraints. In fact, the spread of neoliberal policies may lead to greater competition and market ideology which result in higher cost of borrowing for the deprived poor population. In other words, stronger economic globalization seems to make it harder for MFIs to overcome institutional voids, as small entrepreneurs have less access to credit.

\section{Contributions to Understanding MFIs and Social Enterprises.}

The traditional views on how social enterprises such as MFIs balance their social missions with financial concerns are usually related to the costs associated with serving small loans, the potentially high delinquency rate, and the moral hazard caused by information asymmetry between lenders and borrowers without credit history or collateral (Cull et al., 2007; Hermes, Lensink, \& Meesters, 2011; Sun \& Im, 2015). However, this is far from a complete picture of social enterprises as a special organization type. Organization theories have long embraced the notion that organizations interact with their external environment and institutions that influence their behaviors. An organization's environment also shapes how organizational members make sense of themselves and their 
organization. Globalization as both social and economic forces that bring different types of institutions provides us an ideal ground to study how social enterprises interact with their dynamic environment. By empirically showing that MFIs' interest rates are associated differently with different types of globalization, and that such effects are amplified by the presence of more disadvantaged borrowers, we provide strong evidence on the existence of such organization-environment interaction in the context of social enterprises, and further give insights to how such interaction functions under heterogeneous environment.

Moreover, social enterprises that combine the organizational forms of both business and charity at their cores make them an attractive setting to study hybrid organizing, an important subject that remains largely unexplored in the literature (Battilana \& Lee, 2014). Therefore, our empirical findings also contribute to the broader literature on hybrid organizing and organization by highlighting the importance of institutional contexts in shaping hybrid organizations strategies. Our conjecture that different institutions enacted by globalization galvanize different forms of hybrid organizations—social globalization strengthens the social (charity) function while economic globalization amplifies the business (profit) function—provides new insights on such institutional contexts of hybrid organizing. By understanding the social and economic forces that drive the behavior of MFIs as an important form of hybrid organization, we are thus better able understand the challenges contemporary MFIs (and hybrid organizations in general) face, and therefore offer better policy and management guidance.

Finally our paper also has broader implications for corporations engaging in CSR by studying how organizations can be "doing good" while "doing well” in the formal sector. As globalization has heterogeneous effects on the provision of access to finance in informal economy, its effect on access to 
finance in the formal sector is an interesting but largely unanswered question. We believe our findings

open a ground for more theoretical and empirical research to investigate the effects of globalization on

multinational corporations_as on contrary to MFIs—in fulfilling their social responsibilities.

\section{REFERENCES}

Acemoglu, D., \& Robinsion, J. A. 2012. Why Nations Fail: The Origins of Power, Prosperity, and Poverty. New York: Crown Business .

Aguilera, R. V., Rupp, D. E., Williams, C. A., \& Ganapathi, J. 2007. Putting the S back in corporate social responsibility: A multilevel theory of social change in organizations. Academy of Management Review, 32(3): 836-863.

Ahlin, C., \& Townsend, R. M. 2007. Using repayment data to test across models of joint liability lending. Economic Journal, 117(517), F11-F51.

Armendáriz de Aghion, B., \& Morduch, J. 2005. The Economics of Microfinance. Cambridge, MA: MIT Press.

Ault, J. K., \& Spicer, A. 2013. The institutional context of poverty: State fragility as a predictor of cross-national variation in commercial microfinance lending. Strategic Management Journal, forthcoming.

Bae, J., \& Rowley, C. 2001. The impact of globalization on HRM: the case of South Korea. Journal of World Business, 36(4): 402-428.

Barr, M. S. 2005. Microfinance and financial development. Michigan Journal of International Law, 26 : 271-296.

Battilana, J., \& S. Dorado. 2010. Building sustainable hybrid organizations: The case of commercial microfinance organizations." Academy of Management Journal 53, no. 6

Battilana, J., \& Lee, M. 2014. Advancing research on hybrid organizing - Insights from the study of social enterprises. Academy of Management Annuals, 8(1): 397-441.

Battilana, J., Lee, M., Walker, J., \& Dorsey, C. 2012. In search of the hybrid ideal. Stanfdord Social Innovation Review, 10(3): 51-55.

Bliese, P. D., \& Ployhart, R. E. 2002. Growth modeling using random coefficient models: model building, testing, and illustrations. Organizational Research Methods, 5(4): 362-387.

Brady, D., Beckfield, J., \& Seeleib-Kaiser, M. 2005. Economic globalization and the welfare state in affluent democracies, 1975-2001. American Sociological Review, 70(6): 921-948.

Bruton, G. D., Khavul, S., \& Chavez, H. 2011. Microlending in emerging economies: Building a new line of inquiry from the ground up. Journal of International Business Studies, 42(5): 718-739.

Caudill, S. B., Gropper, D. M., \& Hartarska, V. 2009. Which microfinance institutions are becoming more cost effective with time? Evidence from a mixture model. Journal of Money, Credit and Banking, 41(4): 651-672.

Chakrabarty, S., \& Bass, A. E. 2013. Encouraging entrepreneurship: microfinance, knowledge Support, and the costs of operating in institutional voids. Thunderbird International Business Review, 55(5): 545-562.

Chakrabarty, S., \& Bass, A. E. 2014a. Comparing virtue, consequentialist, and deontological ethics-based corporate social responsibility: Mitigating microfinance risk in institutional voids. 
Journal of Business Ethics, forthcoming.

Chakrabarty, S., \& Bass, A. E. 2014b. Institutionalizing ethics in institutional voids: Building positive ethical strength to serve women microfinance borrowers in negative contexts. Journal of Business Ethics, 199: 529-542.

Cheston, S., \& Kuhn, L. 2002. Empowering Women through Microfinance. New York: UNIFEM.

Cull, R., Demirguc-Kunt, A., \& Morduch, J. 2007. Financial performance and outreach: A global analysis of leading microbanks. Economic Journal, 117(517): 107-133.

Cull, R. J., Demirguc-Kunt, A., \& Morduch, J. 2009. Microfinance tradeoffs: Regulation, competition, and financing. World Bank Policy Research Working Paper 5086.

Dreher, A. 2006. Does globalization affect growth? Evidence from a new index of globalization. Applied Economics 38(10): 1091-1110.

Epstein, K., \& Smith, G. 2007. The ugly side of microlending BusinessWeek: December 13, 2007 http://www.businessweek.com/stories/2007-2012-2012/the-ugly-side-of-microlending.

Hartarska, V., \& Nadolnyak, D. 2007. Do regulated microfinance institutions achieve better sustainability and outreach? Cross-country evidence. Applied Economics, 39(10): 1207-1222.

Hermes, N., Lensink, R., \& Meesters, A. 2011. Outreach and efficiency of microfinance institutions. World Development, 39(6): 938-948.

Hitt, M. A., Beamish, P. W., Jackson, S. E., \& Mathieu, J. E. 2007. Building theoretical and empirical bridges across levels: Multilevel research in management. Academy of Management Journal, 50(6): 1385-1399.

Holcomb, T. R., \& Combs, J. G., Sirmon, D. G., \& Sexton, J. 2010. Modeling levels and time in entrepreneurship research: An illustration with growth strategies and post-IPO performance. Organizational Research Methods, 13(2): 348-389.

Im, J., \& Sun, S. L. 2014. Profits and outreach to the poor: The institutional logics of microfinance institutions. Asia Pacific Journal of Management, Forthcoming.

Ianchovichina, E., \& Lundstrom, S. 2009. Inclusive growth analytics: Framework and application, Policy Research Working Paper Series 4851, The World Bank.

Johnson, S., \& Kidder, T. 1999. Globalization and gender: Dilemmas for microfinance organizations. Small Enterprise Development, 10(3): 4-15.

Johnston, D., \& Morduch, J. 2008. The unbanked: Evidence from Indonesia. World Bank Economic Review, 22(3): 517-537.

Karlan, D. S. 2007. Social connections and group banking. Economic Journal, 117(517), F52-F84.

Klein, K. J., Tosi, H., \& Cannella, A. A. J. 1999. Multilevel theory building: Benefits, barriers, and new developments. Academy of Management Review, 24(2): 248-253.

Khandker, S. R. 2005. Microfinance and poverty: Evidence using panel data from Bangladesh. World Bank Economic Review, 19(2): 263-286.

Khanna, T., \& Palepu, K. G. 1997. Why Focused Strategies May Be Wrong for Emerging Markets.” Harvard Business Review 75(4): 41-51.

Khanna, T., Palepu, K. G., \& Sinha, J. 2005. “Strategies That Fit Emerging Markets.” Harvard Business Review 83(6): 63-76.

Krauss, N., \& Walter, I. 2009. Can microfinance reduce portfolio volatility? Economic Development and Cultural Change, 58(1): 85-100.

La Porta, R., \& Shleifer, A. 2014. Informality and development. Journal of Economic Perspective, forthcoming. 
Levy, D. L. 2008. Political contestation in global production networks. Academy of Management Review, 33(4): 943-963.

Levy, S. 2008. Good Intentions, Bad Outcomes: Social Policy, Informality, and Economic Growth in Mexico. Brookings Institution.

Mair, J. 2010. Social entrepreneurship: Taking sock and looking ahead. In A. Fayolle, \& H. Matlay (Eds.), Handbook of research and social entrepreneurship 15-28. Cheltenham: Edward Elgar.

Mair, J., \& Marti, I. 2009. Entrepreneurship in and around institutional voids: A case study from Bangladesh. Journal of Business Venturing, 24: 419-435.

Mair, J., Marti, I., \& Ventresca, M. 2012. Building inclusive markets in rural Bangladesh: how intermediaries work institutional voids. Academy of Management Journal, 55: 819-850.

Mersland, R., \& Strøm, R. Ø. 2010. Microfinance mission drift? World Development, 38(1): 28-36.

Michels, J. 2012. Do unverifiable disclosures matter? Evidence from peer-to-peer lending. Accounting Review, 87(4): 1385-1413.

Milgram, B. L. 2001. Operationalizing microfinance: Women and craftwork in Ifugao, Upland Philippines. Human Organization, 60(3): 212-224.

Morduch, J. 1999. The microfinance promise. Journal of Economic Literature, 37(4): 1569-1614.

Norris, P. 2000. Global governance and cosmopolitan citizens, in J. S. Nye, \& J. D. Donahue (Eds), Governance in a Globalizing World 155-77. Washington, DC: Brookings Institution Press.

Peterson, M. F., \& Arregle, J. L., \& Martin, X. 2012. Multilevel models in international business research. Journal of International Business Studies, 43(5): 451-457.

Prahalad, C. K. 2005. The Fortune at the Bottom of the Pyramid: Eradicating Poverty Through Profits. Philadelphia: Wharton School Publishing.

Quayes, S. 2011. Depth of outreach and financial sustainability of microfinance institutions. Applied Economics, 44(26): 3421-3433.

Robinson, M. 2001. The Microfinance Revolution: Sustainable Banking for the Poor. Washingtaon, DC: World Bank.

Rodrik, D. 2006. "Goodbye Washington Consensus, Hello Washington Confusion? A Review of the World Bank's Economic Growth in the 1990s: Learning from a Decade of Reform.” Journal of Economic Literature, 44(4): 973-987.

Stiglitz, J. E. 1990. Peer monitoring and credit markets. World Bank Economic Review, 4(3): 351-366.

Stiglitz, J. E. 2002. Globalization and Its Discontents. W. W. Norton: New York.

Sun, S. L., \& Im, J. 2015. Cutting microfinance interest rates: An opportunity co-creation perspective. Entrepreneurship Theory and Practice 39(1): Forthcoming doi: 10.1111/etap.12119.

VanSandt, C.V., \& Sud, M. 2012. Poverty alleviation through partnerships: A road less travelled for business, governments, and entrepreneurs. Journal of Business Venturing, 110(3): 321-332.

Webb, J. W., Tihanyi, L., Ireland, R. D., \& Sirmon, D. G. 2009. You say illegal, I say legitimate: Entrepreneurship in the informal economy. Academy of Management Review, 34(3): 492 - 510.

Yunus, M. 2007. Creating a World Without Poverty. New York: Public Affairs.

Yunus, M., Moingeon, B., \& Lehmann-Ortega, L. 2010. Building social business models: Lessons from the Grameen experience. Long Range Planning, 43(2-3): 308-325.

Zhao, E., \& Wry, T. 2014. Culture, markets, and cross-national variation in the founding and social outreach of microfinance organizations. Working Paper. 
Table 1. Country Distribution of Microfinance Institutions

\begin{tabular}{|c|c|c|c|c|c|}
\hline Country & MFI-year observations & Number of MFIs & Country & MFI-year observations & Number of MFIs \\
\hline Afghanistan & 117 & 18 & Malawi & 59 & 9 \\
\hline Albania & 62 & 6 & Malaysia & 5 & 1 \\
\hline Angola & 11 & 2 & Mali & 131 & 21 \\
\hline Argentina & 112 & 18 & Mexico & 434 & 76 \\
\hline Armenia & 110 & 15 & Moldova & 33 & 5 \\
\hline Azerbaijan & 203 & 27 & Mongolia & 58 & 9 \\
\hline Bangladesh & 462 & 79 & Montenegro & 18 & 4 \\
\hline Belarus & 4 & 1 & Morocco & 112 & 11 \\
\hline Belize & 4 & 1 & Mozambique & 85 & 11 \\
\hline Benin & 138 & 22 & Myanmar & 3 & 1 \\
\hline Bhutan & 4 & 1 & Namibia & 11 & 2 \\
\hline Bolivia & 279 & 28 & Nepal & 289 & 46 \\
\hline Bosnia and Herzegovina & 179 & 17 & Nicaragua & 278 & 34 \\
\hline Brazil & 186 & 40 & Niger & 46 & 8 \\
\hline Bulgaria & 169 & 25 & Nigeria & 230 & 71 \\
\hline Burkina Faso & 64 & 15 & Pakistan & 232 & 33 \\
\hline Burundi & 28 & 6 & Palestine & 69 & 8 \\
\hline Cambodia & 184 & 18 & Panama & 29 & 5 \\
\hline Cameroon & 128 & 27 & Papua New Guinea & 16 & 2 \\
\hline Central African Republ & 7 & 1 & Paraguay & 66 & 7 \\
\hline Chad & 16 & 3 & Peru & 616 & 70 \\
\hline Chile & 40 & 7 & Philippines & 677 & 108 \\
\hline China & 215 & 67 & Poland & 21 & 4 \\
\hline Colombia & 267 & 39 & Republic of the Congo & 30 & 5 \\
\hline Comoros & 3 & 3 & Romania & 64 & 8 \\
\hline Costa Rica & 114 & 17 & Russia & 416 & 103 \\
\hline Croatia & 17 & 2 & Rwanda & 63 & 11 \\
\hline Democratic Republic of & 82 & 22 & Saint Lucia & 2 & 1 \\
\hline Dominican Republic & 86 & 13 & Samoa & 13 & 1 \\
\hline Ecuador & 483 & 58 & Senegal & 144 & 26 \\
\hline Egypt & 124 & 16 & Serbia & 46 & 4 \\
\hline El Salvador & 135 & 18 & Sierra Leone & 49 & 13 \\
\hline
\end{tabular}




\begin{tabular}{|c|c|c|c|c|c|}
\hline Ethiopia & 177 & 23 & Slovakia & 3 & 1 \\
\hline Fiji & 4 & 1 & South Africa & 70 & 17 \\
\hline Gabon & 3 & 1 & South Sudan & 14 & 4 \\
\hline Gambia & 11 & 2 & Sri Lanka & 156 & 27 \\
\hline Georgia & 109 & 16 & Sudan & 11 & 2 \\
\hline Ghana & 284 & 77 & Suriname & 5 & 3 \\
\hline Grenada & 4 & 2 & Swaziland & 9 & 1 \\
\hline Guatemala & 167 & 23 & Syria & 19 & 3 \\
\hline Guinea & 43 & 8 & Tajikistan & 229 & 44 \\
\hline Guinea-Bissau & 12 & 4 & Tanzania & 115 & 16 \\
\hline Haiti & 67 & 9 & Thailand & 14 & 3 \\
\hline Honduras & 179 & 23 & Timor-Leste & 20 & 3 \\
\hline Hungary & 4 & 1 & Togo & 98 & 16 \\
\hline India & 952 & 188 & Tonga & 3 & 1 \\
\hline Indonesia & 335 & 74 & Trinidad and Tobago & 11 & 2 \\
\hline Iraq & 61 & 12 & Tunisia & 13 & 1 \\
\hline Ivory Coast & 79 & 23 & Turkey & 13 & 2 \\
\hline Jamaica & 11 & 3 & Uganda & 166 & 29 \\
\hline Jordan & 84 & 8 & Ukraine & 25 & 3 \\
\hline Kazakhstan & 200 & 43 & Uruguay & 7 & 2 \\
\hline Kenya & 208 & 33 & Uzbekistan & 134 & 34 \\
\hline Kosovo & 99 & 12 & Vanuatu & 2 & 1 \\
\hline Kyrgyzstan & 220 & 46 & Venezuela & 16 & 2 \\
\hline Laos & 33 & 20 & Vietnam & 153 & 35 \\
\hline Lebanon & 41 & 5 & Yemen & 48 & 9 \\
\hline Liberia & 11 & 3 & Zambia & 48 & 9 \\
\hline Macedonia & 40 & 4 & Zimbabwe & 27 & 7 \\
\hline Madagascar & 110 & 15 & Total & & \\
\hline
\end{tabular}


Table 2. Descriptive Statistics

\begin{tabular}{lllllll}
\hline Variable & Obs & Mean & Median & Std. Dev. & Min & Max \\
\hline Interest rate of MFI loan portfolio (winsor.) & 7217 & 0.334 & 0.290 & 0.181 & 0.059 & 1.003 \\
Social globalization & 12519 & 37.330 & 37.790 & 11.636 & 15.190 & 82.060 \\
Economic globalization & 11833 & 53.400 & 53.320 & 12.310 & 25.690 & 89.620 \\
Regulated MFI & 12942 & 0.598 & 1 & 0.490 & 0 & 1 \\
Rule of Law & 13333 & -0.628 & -0.600 & 0.447 & -2.230 & 1.370 \\
Borrower Community & 11556 & 0.024 & 0.014 & 0.031 & 0 & 0.162 \\
MFI age & 13355 & 9.013 & 9 & 3.830 & 0 & 17 \\
Average loan balance/ GNI per capita (\%) & 10553 & 0.869 & 0.305 & 5.031 & 0 & 419.623 \\
Female borrower rate & 9850 & 0.650 & 0.650 & 0.284 & 0 & 6.689 \\
Debt-to-asset ratio & 12540 & 0.639 & 0.735 & 1.454 & -155.066 & 19.353 \\
Non-profit MFI & 12783 & 0.604 & 1 & 0.489 & 0 & 1 \\
Operational Efficiency & 9563 & 0.311 & 0.196 & 0.584 & -0.060 & 22.180 \\
Administrative Expenses & 7197 & 0.086 & 0.064 & 0.088 & -0.066 & 1.927 \\
Employee Productivity & 11605 & 131.220 & 100 & 208.050 & 0 & 13709 \\
Ln(GDP per capita) & 12796 & 7.287 & 7.185 & 1.059 & 4.522 & 9.955 \\
\hline
\end{tabular}


Table 3. Correlation Matrix of Key Independent Variables

\begin{tabular}{|c|c|c|c|c|c|c|c|c|c|c|c|c|c|c|}
\hline & (1) & $(2)$ & (3) & (4) & (5) & (6) & (7) & (8) & (9) & (10) & (11) & $(12)$ & (13) & (14) \\
\hline (1) Social Globalization & 1.0000 & & & & & & & & & & & & & \\
\hline (2) Economic Globalization & 0.5977 & 1.0000 & & & & & & & & & & & & \\
\hline (3) Regulated MFI & -0.2147 & -0.0698 & 1.0000 & & & & & & & & & & & \\
\hline (4) Rule of Law & 0.3199 & 0.2051 & -0.0705 & 1.0000 & & & & & & & & & & \\
\hline (5) Borrower Community & -0.1230 & 0.1315 & -0.0159 & -0.2236 & 1.0000 & & & & & & & & & \\
\hline (6) MFI Age & -0.1031 & -0.1104 & -0.0746 & -0.0199 & 0.3523 & 1.0000 & & & & & & & & \\
\hline (7) Average Loan Balance & -0.0613 & 0.0330 & 0.1883 & -0.1281 & -0.0035 & -0.0758 & 1.0000 & & & & & & & \\
\hline (8) Female Borrower Rate & -0.2287 & -0.2367 & -0.1909 & 0.0516 & 0.0753 & 0.1646 & -0.3256 & 1.0000 & & & & & & \\
\hline (9) Debt-to-asset Ratio & -0.1997 & -0.2128 & 0.1791 & -0.0518 & 0.1042 & 0.2141 & 0.0473 & -0.0001 & 1.0000 & & & & & \\
\hline (10) Non-profit MFI & 0.1101 & -0.0213 & -0.4709 & 0.0248 & 0.0659 & -0.0001 & -0.1038 & 0.1260 & -0.1443 & 1.0000 & & & & \\
\hline (11) Operational Efficiency & -0.0113 & 0.0060 & -0.1005 & 0.0204 & -0.1274 & -0.1121 & -0.1101 & 0.1109 & -0.1224 & -0.0084 & 1.0000 & & & \\
\hline (12) Administrative Expenses & 0.0058 & 0.0511 & -0.1223 & 0.0101 & -0.1671 & -0.1666 & -0.1315 & 0.1231 & -0.1034 & -0.0240 & 0.6402 & 1.0000 & & \\
\hline (13) Employee Productivity & -0.1108 & -0.1539 & 0.0169 & 0.1100 & -0.0270 & 0.0341 & -0.1731 & 0.1856 & 0.0418 & -0.0001 & -0.0275 & -0.0254 & 1.0000 & \\
\hline (14) Ln(GDP per capita) & 0.7724 & 0.5694 & -0.2702 & 0.2946 & 0.0270 & 0.1085 & -0.1722 & -0.1750 & -0.1357 & 0.0546 & 0.0401 & 0.0528 & -0.0697 & 1.0000 \\
\hline
\end{tabular}


Table 4. Regression Results: Globalization and Microfinance Interest Rates

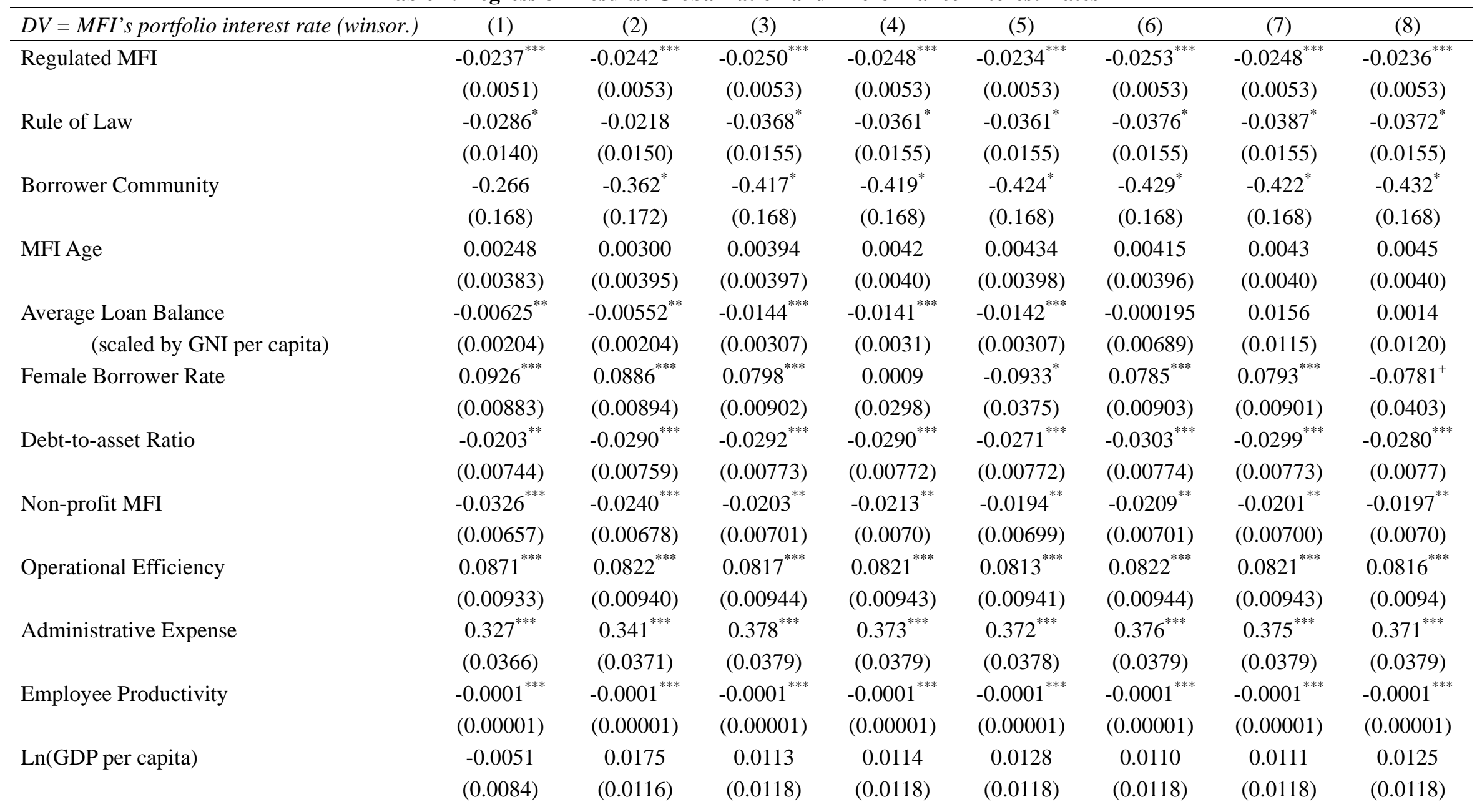


Table 5. Robustness Checks: Country Fixed Effects

\begin{tabular}{|c|c|c|c|c|}
\hline $\begin{array}{l}D V=\text { MFI's portfolio interest rate } \\
\text { (winsor.) }\end{array}$ & (1) & (2) & (3) & (4) \\
\hline Social Globalization & $\begin{array}{c}-0.0213 * * * \\
(0.0033)\end{array}$ & & $\begin{array}{c}-0.0202 * * * \\
(0.0032)\end{array}$ & \\
\hline Economic Globalization & & $\begin{array}{r}0.0336 * * \\
(0.0123)\end{array}$ & & $\begin{array}{c}0.0362 * * \\
(0.0124)\end{array}$ \\
\hline Female Borrower Rate & $\begin{array}{c}0.0284 \\
(0.0296)\end{array}$ & $\begin{array}{l}-0.0945^{*} \\
(0.0396)\end{array}$ & $\begin{array}{c}0.0860 * * * \\
(0.0095)\end{array}$ & $\begin{array}{c}0.0782 * * * \\
(0.0095)\end{array}$ \\
\hline $\begin{array}{l}\text { Average Loan Balance } \\
\text { (scaled by GNI per capita) }\end{array}$ & $\begin{array}{l}-0.0056^{*} \\
(0.0022)\end{array}$ & $\begin{array}{c}-0.0189 * * * \\
(0.0037)\end{array}$ & $\begin{array}{c}0.0057 \\
(0.0046)\end{array}$ & $\begin{array}{c}0.0066 \\
(0.0117)\end{array}$ \\
\hline $\begin{array}{l}\text { Social Globalization } \\
\quad \times \text { Female Borrower Rate }\end{array}$ & $\begin{array}{l}0.0015^{*} \\
(0.0007)\end{array}$ & & & \\
\hline $\begin{array}{l}\text { Economic Globalization } \\
\quad \times \text { Female Borrower Rate }\end{array}$ & & $\begin{array}{c}0.0032 * * * \\
(0.0007)\end{array}$ & & \\
\hline $\begin{array}{l}\text { Social Globalization } \\
\quad \times \text { Average Loan Balance }\end{array}$ & & & $\begin{array}{l}-0.0004 * * \\
(0.0046)\end{array}$ & \\
\hline $\begin{array}{l}\text { Economic Globalization } \\
\quad \times \text { Average Loan Balance }\end{array}$ & & & & $\begin{array}{l}-0.0005^{*} \\
(0.0002)\end{array}$ \\
\hline Other Control Variables & Yes & Yes & Yes & Yes \\
\hline Year Effects & Yes & Yes & Yes & Yes \\
\hline Country Effects & Yes & Yes & Yes & Yes \\
\hline Log Likelihood & 3244.824 & 3183.1431 & 3246.5601 & 3175.7841 \\
\hline $\mathrm{N}$ & 3499 & 3330 & 3499 & 3330 \\
\hline
\end{tabular}


Table 6. Robustness Checks: Sub-indices of Globalization

\begin{tabular}{|c|c|c|c|c|c|c|c|c|c|c|}
\hline $\begin{array}{l}D V=\text { MFI's portfolio interest rate } \\
\text { (winsor.) }\end{array}$ & (1) & (2) & (3) & (4) & (5) & (6) & (7) & (8) & (9) & $(10)$ \\
\hline Personal Contact & $-0.00201 *$ & & & & & $-0.00166+$ & & & & \\
\hline (Social Globalization) & $(0.000947)$ & & & & & $(0.000886)$ & & & & \\
\hline Information Flows & & $-0.00191 *$ & & & & & -0.00127 & & & \\
\hline (Social Globalization) & & $(0.0009)$ & & & & & $(0.000867)$ & & & \\
\hline Cultural Proximity & & & $-0.0013 *$ & & & & & -0.000905 & & \\
\hline (Social Globalization) & & & $(0.0007)$ & & & & & $(0.000626)$ & & \\
\hline Actual Flows & & & & -0.0005 & & & & & $0.00168 *$ & \\
\hline (Economic Globalization) & & & & $(0.0009)$ & & & & & $(0.000807)$ & \\
\hline $\begin{array}{l}\text { Restrictions } \\
\qquad \text { (Economic Globalization) }\end{array}$ & & & & & $\begin{array}{c}0.0005 \\
(0.0011)\end{array}$ & & & & & $\begin{array}{l}0.00201+ \\
(0.00103)\end{array}$ \\
\hline Female Borrower Rate & $\begin{array}{c}0.0701^{* *} \\
(0.0238)\end{array}$ & $\begin{array}{c}0.0424 \\
(0.0325)\end{array}$ & $\begin{array}{c}0.0779 * * * \\
(0.0147)\end{array}$ & $\begin{array}{r}-0.0573+ \\
(0.0332)\end{array}$ & $\begin{array}{l}-0.0330 \\
(0.0356)\end{array}$ & $\begin{array}{c}0.0923 * * * \\
(0.00951)\end{array}$ & $\begin{array}{c}0.0838 * * * \\
(0.00961)\end{array}$ & $\begin{array}{c}0.0865 * * * \\
(0.00958)\end{array}$ & $\begin{array}{c}0.0842 * * * \\
(0.00943)\end{array}$ & $\begin{array}{l}0.0769 * * * \\
(0.00973)\end{array}$ \\
\hline $\begin{array}{l}\text { Average Loan Balance } \\
\qquad \text { (scaled by GNI per capita) }\end{array}$ & $\begin{array}{c}-0.0060 * * \\
(0.0022)\end{array}$ & $\begin{array}{l}-0.0057^{*} \\
(0.00221)\end{array}$ & $\begin{array}{l}-0.0057^{*} \\
(0.0022)\end{array}$ & $\begin{array}{c}-0.0064^{* *} \\
(0.0022)\end{array}$ & $\begin{array}{c}-0.0187 * * * \\
(0.0038)\end{array}$ & $\begin{array}{l}-0.00649 \\
(0.00643)\end{array}$ & $\begin{array}{c}0.00694 \\
(0.00654)\end{array}$ & $\begin{array}{l}-0.00396+ \\
(0.00228)\end{array}$ & $\begin{array}{c}0.0129+ \\
(0.00675)\end{array}$ & $\begin{array}{l}-0.00127 \\
(0.0118)\end{array}$ \\
\hline $\begin{array}{l}\text { Social Globalization } \\
\quad \times \text { Female Borrower Rate }\end{array}$ & $\begin{array}{c}0.0006 \\
(0.0006)\end{array}$ & $\begin{array}{c}0.0008 \\
(0.0006)\end{array}$ & $\begin{array}{c}0.0004 \\
(0.0004)\end{array}$ & & & & & & & \\
\hline $\begin{array}{l}\text { Economic Globalization } \\
\quad \times \text { Female Borrower Rate }\end{array}$ & & & & $\begin{array}{c}0.0027 * * * \\
(0.0006)\end{array}$ & $\begin{array}{r}0.0020 * * \\
(0.0006)\end{array}$ & & & & & \\
\hline $\begin{array}{l}\text { Social Globalization } \\
\quad \times \text { Average Loan Balance }\end{array}$ & & & & & & $\begin{array}{r}0.0000124 \\
(0.000166)\end{array}$ & $\begin{array}{l}-0.000261 * \\
(0.000127)\end{array}$ & $\begin{array}{l}-0.0004 * * * \\
(0.000106)\end{array}$ & & \\
\hline $\begin{array}{l}\text { Economic Globalization } \\
\quad \times \text { Average Loan Balance }\end{array}$ & & & & & & & & & $\begin{array}{l}-0.0004^{* *} \\
(0.000133)\end{array}$ & $\begin{array}{l}-0.000334 \\
(0.000209)\end{array}$ \\
\hline Other Control Variables & Yes & Yes & Yes & Yes & Yes & Yes & Yes & Yes & Yes & Yes \\
\hline Year Effects & Yes & Yes & Yes & Yes & Yes & Yes & Yes & Yes & Yes & Yes \\
\hline Log likelihood & 3056.749 & 3046.398 & 3048.4438 & 3092.0297 & 2959.402 & 3056.2362 & 3047.566 & 3053.7391 & 3086.7659 & 2955.4524 \\
\hline $\mathrm{N}$ & 3475 & 3426 & 3499 & 3467 & 3292 & 3475 & 3426 & 3499 & 3467 & 3292 \\
\hline
\end{tabular}




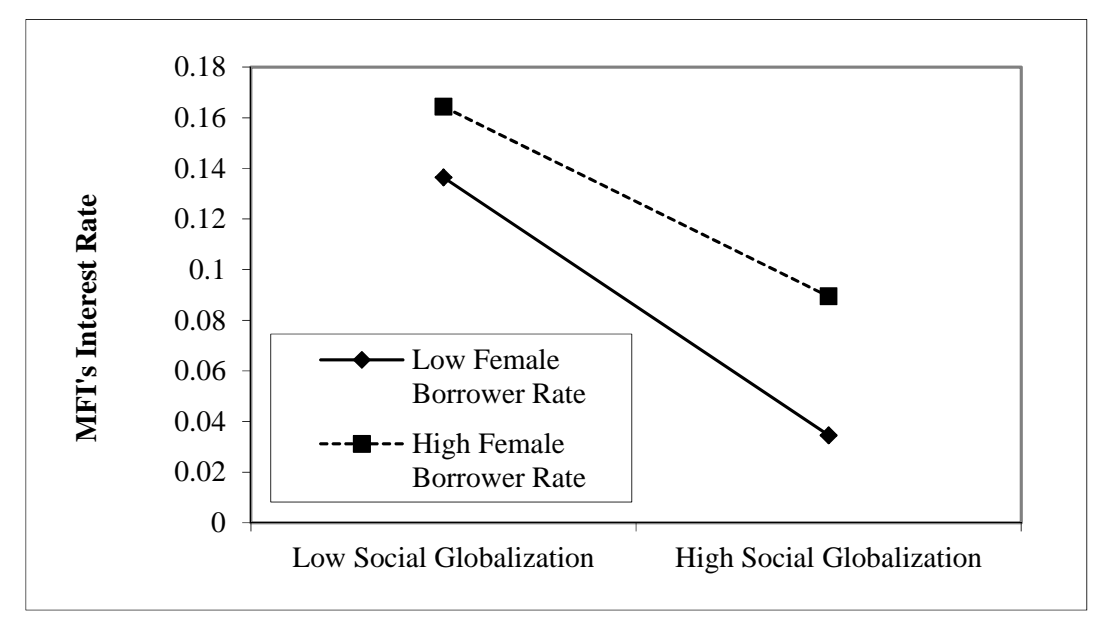

A. Moderating Effects of Female Borrower Rate on Social Globalization

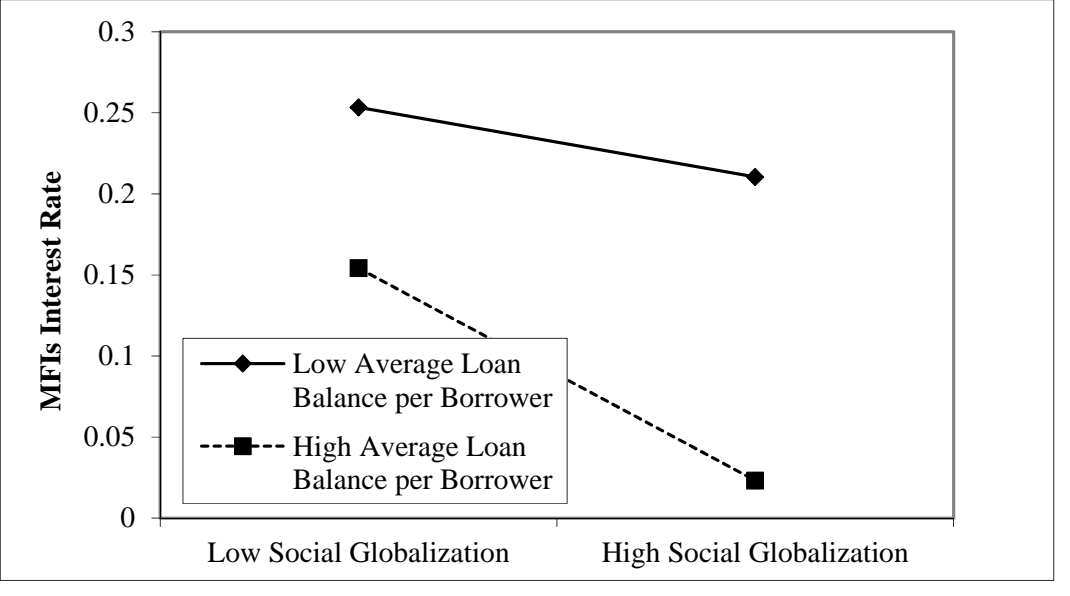

C. Moderating Effects of Poor Borrowers on Social Globalization

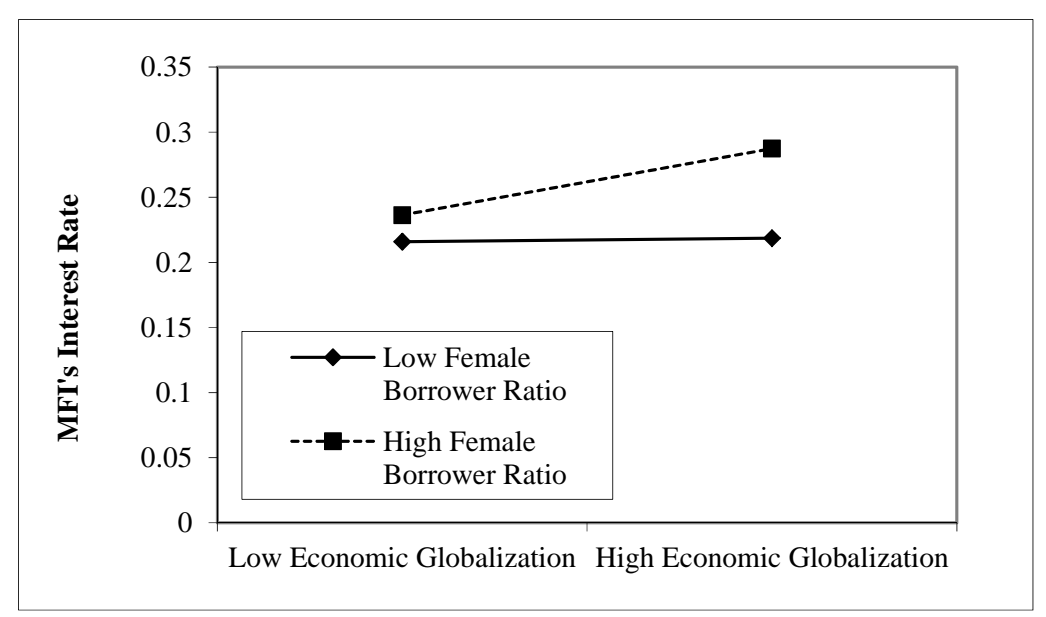

B. Moderating Effects of Female Borrower Rate on Economic Globalization

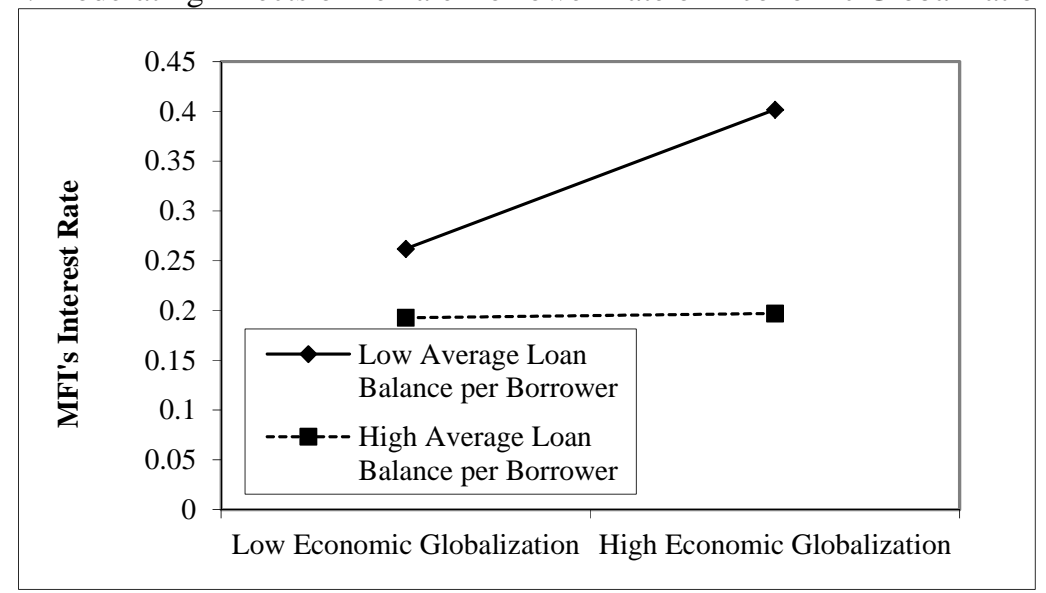

D. Moderating Effects of Poor Borrowers on Economic Globalization

Figure 1. The Moderating Effects of Female Borrower Rate and Poor Borrowers on Globalization and MFI’s Interest Rate 


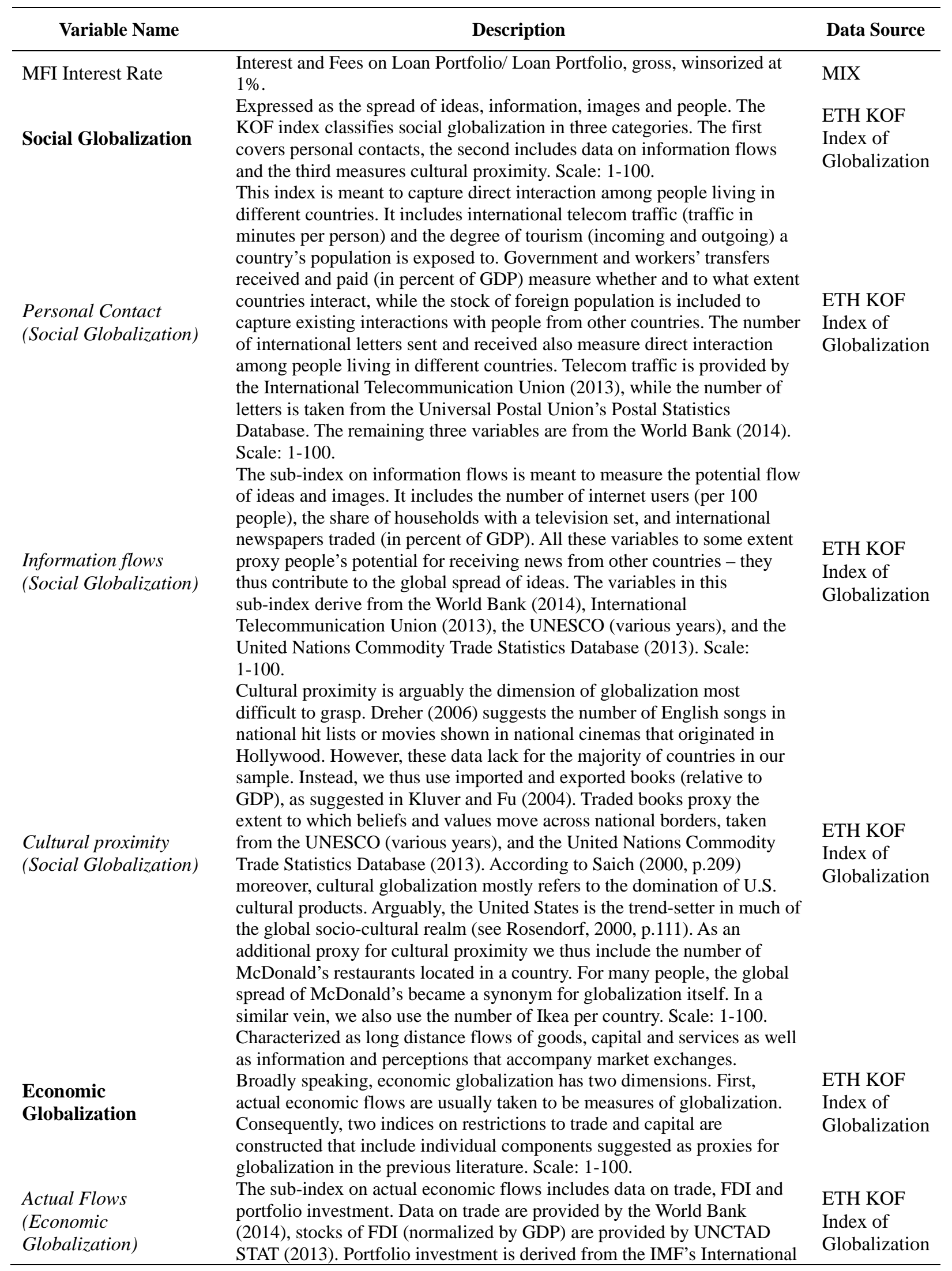




\section{Restrictions \\ (Economic \\ Globalization)}

Regulated MFI

Borrower Community

Average Loan Balance

Female Borrowers

Debt-to-asset Ratio

Non-Profit MFI

Operational Efficiency

Administrative Expense

Employee Productivity

MFIs Legal Status

MFI Size

MFI Target Market

MFI Age

Financial

Intermediation Types

GDP Per Capita

Rule of Law
Financial Statistics (January 2014). More specifically, trade is the sum of a country's exports and imports and portfolio investment is the sum of a country's stock of assets and liabilities (all normalized by GDP). While these variables are straightforward, income payments to foreign nationals and capital are included to proxy for the extent that a country employs foreign people and capital in its production processes. Scale: 1-100. The Restrictions index refers to restrictions on trade and capital using hidden import barriers, mean tariff rates, taxes on international trade (as a share of current revenue) and an index of capital controls. Given a certain level of trade, a country with higher revenues from tariffs is less globalized. To proxy restrictions of the capital account, an index based on data by Gwartney et al. (2013) is employed. This index is based on the IMF's Annual Report on Exchange Arrangements and Exchange Restrictions and includes 13 different types of capital controls. The index is constructed by subtracting the number of restrictions from 13 and multiplying the result by 10 . The indices on mean tariff rates and hidden import barriers are also derived from Gwartney et al. (2013). Mean tariff rates originate from various sources. Gwartney et al. allocated a rating of 10 to countries that do not impose any tariffs. As the mean tariff rate increases, countries are assigned lower ratings. The rating will decline toward zero as the mean tariff rate approaches 50 percent (which is usually not exceeded by most countries among their sample). The original source for hidden import barriers, finally, is the World Economic Forum's Global Competitiveness Report (various issues). Scale: 1-100.

A dummy variable measured whether MFIs are regulated by a government or not.

The accumulated number of individuals or entities who currently have an outstanding loan balance with the MFIs in the focal country, adjusted by country population, log- transformed.

Average Loan Balance per Borrower/ GNI per capita.

The ratio of the number of active female borrowers to the total number of active borrowers (\%).

The ratio of the focal MFI's total debts to total assets. MIX Focal MFI registered as a non-profit organization. $\quad$ MIX

Operating Expense / Loan Portfolio. $\quad$ MIX

(Administrative Expense + Depreciation)/ Assets, average. MIX

Borrowers per staff, measured as the ratio of the number of active MIX

borrowers to the number of focal MFI's staff members.

Categorical variable: registered as bank; Credit Union, NBFI, Rural bank, and Others.

Categorical variable for loan portfolio: Large, Medium, and Small scale of gross loan portfolio.

Categorical variable: Target market: low end; Broad; High end, and Small business.

Categorical variable: New (1-4 years); Young (5-8 years), ad Mature

(more than 8 years).

Categorical variable: Non FI (No voluntary savings); Low FI (Voluntary savings $<20 \%$ of total assets); High FI (Voluntary savings $>=20 \%$ of total assets).

Total GDP is divided by the resident population on a country, log-transformed.

perceptions of the extent to which agents have confidence in and abide by the rules of society, and in particular the quality of contract enforcement,

World Bank

ETH KOF

Index of

Globalization

MIX

MIX

MIX

MIX

MIX

MIX

MIX

MIX

MIX

World Bank property rights, the police, and the courts, as well as the likelihood of crime and violence. 